\title{
Improvement of the Popularity and Effectiveness of College Counselors in Ideological and Political Education Based on WeChat
}

\author{
Wenli Chen \\ City College of Dongguan University of Technology \\ Dongguan, China 523419
}

\begin{abstract}
As the most popular social media at present, WeChat has roundly involved in the learning and life of college students, profoundly influencing their behavioral pattern and ideology. According to the investigation and sample analysis on the utilization of WeChat by college counselors and students, college counselors have achieved results in using the carrier of WeChat in the daily ideological and political education of college students, but some problems also exist. Counselors can exert the advantages of the carrier WeChat in the ideological and political education of college students through strengthening the training of WeChat ability, the construction of the Official Accounts and the media literacy education of college students, in order to improve the popularity and effectiveness of the ideological and political education of college students.
\end{abstract}

Keywords-WeChat; colleges; ideological and political education; popularity; effectiveness

\section{INTRODUCTION}

On the national conference on the ideological and political work in colleges and universities, General Secretary Xi Jinping emphasizes, "The new media technology must be used to activate the ideological and political work in colleges, promoting the high degree of integration between the traditional advantages of ideological and political work and the information technology and making it more epochal and attractive." As the most popular social media at present, WeChat becomes a part of the learning and life of the young college students at the meantime deeply influences their behavioral pattern and ideology. As the first-line manager of college students in the daily ideological and political education work, college counselors shall pay attention to the imperceptible influence of the WeChat on students and explore the improvement of the popularity and effectiveness of the daily ideological and political education on college students through WeChat.

\section{ANALYZE THE FEASIBILITY OF TAKING WECHAT AS} THE CARRIER FOR THE COLLEGE COUNSELORS TO CONDUCT THE IDEOLOGICAL AND POLITICAL EDUCATION WORK

WeChat refers to a free social contact APP on the smart phone terminal unveiled by the Tencent Company in January 2011 in order to provide instant messaging (IM). It can realize the real-time voice information, location, video, picture and text at the same time provide such service functions as "WeChat Pay", "Try to Search", "Shake", "Moments", "Public Platform", "Mini Programs", and "People Nearby" according to the needs of users. WeChat has become a necessary mobile phone APP of mobile phone users by virtue of the abundant and convenient functions. At the close of June 2016, the number of monthly active users of WeChat has reached 806 million. WeChat has covered above $94 \%$ of the smart phones in China, and the WeChat users worldwide cover more than 200 countries. People born after the 1980s and the 1990s become the main users of WeChat. Therefore, college counselors shall know and grasp the skills to apply WeChat and give play to the role of $\mathrm{WeChat}$ in improving the pertinence and effectiveness of the daily ideological and political education work.

\section{A. The Strong Tie and Authenticity of We Chat Avail to Improve the Popularity of the Daily Ideological and Political Education in Colleges and Universities}

The most important difference between WeChat and other applications for social contact and IM is that the relationship between users on WeChat is authentic. WeChat users add friends mainly through adding the contacts on mobile phones and QQ friends, adding friends nearby through Friend Radar and scanning QR Code. These friends are mainly acquaintances of users in real life, belonging to the strong tie in the social network. The strong tie and authenticity between WeChat users can guarantee the privacy of communication on WeChat and make users always play a dominant role in the one-to-one communication and the Moments of WeChat. Users have the speaking right and the leading position in the communication of topics. The equal position of both sides in the chatting can be guaranteed. After becoming friends on the WeChat, the counselors and friends are always in the equal position on the WeChat platform. Counselors can present their work experience, feelings and concepts in the Moments to attract the attention of students, turning the dull explanation into the sincere emotional communication to realize the ideological guidance; they can also share their life in the Moments and let students know that counselors are not out of reach but individuals with ample emotions and surrounded by little things, so that it can narrow the distance between counselors and students and build a bridge the subject and the object of the daily ideological and political education; when 
students encounter problems or feel confused, counselors can exclude the difficulty and anxiety through WeChat in order to better help students to grow. Therefore, the popularity of the daily ideological and political education will be better improved by virtue of WeChat.

\section{B. The Immediacy and Accuracy of WeChat Avails to Improve the Pertinence of the Daily Ideological and Political Education in Colleges and Universities}

The transmission of WeChat is real-time and accurate. Users can carry out real-time communication accurately with some individual or group through text, voice and video whenever and wherever possible through WeChat and share the little things in life. By virtue of the WeChat Platform, Counselors can directly pass the information of the daily education and management and service like the appraisal of the most outstanding and advanced individuals, the prize for attendance, student loan, occupational guidance, innovation and entrepreneurship, psychological counseling and theme education in the fastest way, realizing the seamless joint of information; they can interact with the students most timely to understand the practical difficulties and real demands of students and improve the efficiency in the daily management work of students. At the same time, according to the click rate, comments and messages received after pushing information through the WeChat Official Platform, counselors can timely know about the effect and recognition degree of the daily management work and make the daily management work opener and more transparent, availing the continuous improvement of the work level; they can open the direct access to suggestion feedback according to the opinions and suggestions of students collected on the WeChat Official Platform, reducing the problems of slow speed of information transfer, errors and distortion and improving the management level and service level of the student work. In this way, the effectiveness and pertinence of the daily ideological and political education work will be strengthened.

\section{The Abundant Language and the Diversified Functions of Wechat Are Beneficial to the Improvement of the Diversity of the Daily Ideological and Political Education in Colleges and Universities}

The interpersonal media diffusion formed by the language and some non-verbal signs including pictures, texts, real-time voice call and video call provided by WeChat has tremendously returned the face-to-face transmission with the highest richness, compared with other media. At the same time, WeChat has powerful functions, such as chatting, Moments, public platform, payment, search, look, Mini Programs, shopping and games. The strong language and functions of WeChat can help counselors to better conduct the daily ideological and political education. Counselors establish the most timely communication and contact with students through "real-time voice call" and "video call" and close the gap between students through emoji package, pictures and network language in communication and establish better communication. The public platform with rich functions can help counselors to push articles with pictures to convey the newest notifications and news, pushing micro-videos to convey the newest news and trends and theme education and pushing video classroom and micro live streaming to explain knowledge to students.

\section{THE SituATION OF COLLEGES AND UNIVERSITIES IN USING WECHAT TO CARRY OUT THE DAILY IDEOLOGICAL AND POLITICAL EDUCATION WORK}

With college students and counselors as the respondents, the author distributes 510 network questionnaires to college students on campus of eight colleges and universities in Dongguan city through the system of "SO JUMP", collecting 510 questionnaires, with 510 valid questionnaires and the effective rate of $100 \%$; distribute 200 network questionnaires to counselors in Guangzhou, Foshan and Dongguan of Guangdong province, with 200 valid questionnaires and the effective rate of $100 \%$. The influence of WeChat on the daily ideological and political education work of college students and the situation that college counselors use WeChat to conduct the ideological and political education can be known through questionnaire survey, interview on key objects and sample analysis.

\section{A. The Analysis on the Situation that College Students Use Wechat}

1) College students strongly depend on the WeChat and observe WeChat can improve the interpersonal relationship: According to the survey, $93.92 \%$ of college students say WeChat is the most frequently-used App by them for social contact. The main three reasons to use WeChat are as follows: strengthen the contact and communication; people around are using and they do not want to drop behind; kill time. In addition, $51.76 \%$ of college students will log in the WeChat all day long, $20 \%$ of students say they will be online on the WeChat for 6 to 12 hours and $12.44 \%$ of students spend 2 to 5 hours in applying WeChat. $71.18 \%$ of students think the most important function of WeChat is to send and receive messages and $20.59 \%$ of students like browse or release messages in Moments. For the Moments, college students like to browse the information sent by others most, accounting for $55.69 \%$ and then click Like or Comment for others and last release contents to share little things in life with others. $44.9 \%$ of students think WeChat can make the relationship between others and him/her closer, and $91.17 \%$ of students use WeChat to increase the quantity of information obtained. Obviously, WeChat has a high popularizing rate among college students. College students have a strong dependency on WeChat and pay attention to the communicative roles of WeChat, but they neither fully utilize the functions of WeChat nor like to share little things in life through the Moments very much. Therefore, counselors shall pay high attention to WeChat, the APP for social contact, and give play to the functional advantages of WeChat, taking it as an important carrier of the daily ideological and political education.

2) The majority of college students pay attention to the Official Accounts of the school, colleges and departments to obtain various related information: Most college students will 
pay attention to the WeChat Official Accounts beneficial to them. In regard to the contents of Official Accounts, they care about "whether the contents have relation with them", accounting for $48.63 \%$; of course, they will also care about problems such as "whether the contents are original" and "how about the quality of pictures", accounting for $19.21 \%$. For the Official Accounts or service account of the school, colleges and department closely related to them, $88.04 \%$ of students "have paid attention to it" and only $4.71 \%$ of students "do not want to pay attention to it". A total of $54.71 \%$ of students pay attention to the Official Account or service account of the school, colleges and department to search the information related to them (such as water and electricity, and academic record), and a total of $29.22 \%$ of college students will pay attention to the hot news of the school, expecting to obtain learning resources and other download resources. Since students have the habit to pay attention to the Official Accounts or service account of the school, colleges and department and care about the information closely related to them, counselors can release news and trends, consultation and notifications through the existing Official Accounts or service account of the units and departments or establishing the public platforms independently, sending day-to-day business like the confirmation of some information, enrollment, leave and file download to the Official Account, in order to complete the related work efficiently.

3) The majority of college students is not disgusted with the ideological and political education through the WeChat platform and become WeChat friends with counselors: A total of $31.18 \%$ of college students can accept the ideological and political education through WeChat and $36.47 \%$ of students are indifferent to it. When contacting with the counselors through WeChat, a total of $78.24 \%$ of students have added the WeChat of counselors but $37.45 \%$ of students are more willing to carry out the face-to-face communication with the counselors. If the counselors open the Official Accounts, a total of $50.98 \%$ of students will pay attention to it, while $36.86 \%$ of students think they must see the contents before determining whether to pay close attention to it. A total of $37.84 \%$ of students are "willing" to let the counselors see their Moments, and $29.41 \%$ of students will set groups for the counselors. Because of being disgusted with the traditional ideological and political education, some students resist the ideological and political education through WeChat. The counselors can deeply excavate the functions of WeChat and convey the contents of the ideological and political education through vivid and vigorous ways like micro-videos, cartoons and image-text. Moreover, most college students have become friends with the counselors on WeChat. Counselors can educate and lead students in the communication through WeChat in daily life, in order to "influence them imperceptibly". At the meantime, the counselors can consider establishing the WeChat Official Accounts of their own, in order to better conduct the ideological and political education on students.

\section{B. The Analysis on the Situation that the Counselors Carry out the Daily Ideological and Political Education through We Chat}

1) The popularizing rate of WeChat among counselors is high, and counselors identify the educational value of WeChat: A total of 200 counselors participate in the survey, and all of them are using the WeChat. $86.14 \%$ of counselors address WeChat is the software for social contact that is most frequently-used by them. The top three reasons for them to use WeChat are as follows: strengthen the contact and communication, job demand and get information through following the WeChat official accounts. WeChat is a good helper of the work of counselors. The online work of the counselors through $\mathrm{WeChat}$ has become a new trend. A total of $76.23 \%$ of counselors say they will spend more than 2 hours in using WeChat, and the counselors who use the WeChat all day long account for $40.59 \%$. $84.61 \%$ of counselors think it is necessary to build WeChat as the carrier to strengthen the daily ideological and political education and identify the value of $\mathrm{WeChat}$ that serves as the educational carrier.

2) The majority of counselors carries out the student work through WeChat and thinks it helps to grasp the dynamic state of students: WeChat has provided new carrier and way for the counselors to conduct the daily ideological and political education work for students, and has achieved certain results. First, the relationship between teachers and students becomes more harmonious because of the interaction on the WeChat. A total of $96.04 \%$ of counselors say they have added the students and become WeChat friends with them, frequently paying attention to the dynamic state of students in the Moments. They will click the Like or Comment on some information sent by the students. Similarly, students will click the Like or Comment on the dynamic state sent by counselors. The frequent interaction between teachers and students improves the relationship between them. A total of $75.25 \%$ of counselors identify the WeChat has strengthened their relationship with the students. Second, WeChat is beneficial to the implementation of student work. A total of $89.11 \%$ of counselors say they will communicate with colleagues and students through WeChat. $85.15 \%$ of counselors release the work notice through WeChat group and pay close attention to the change of thoughts of students through WeChat Moments. $62.38 \%$ of counselors propagandize through WeChat Official Accounts. $60.4 \%$ of counselors provide psychological counseling and answer the questions and solve the difficulties on school work. Third, some counselors innovate in the work pattern by virtue of WeChat. A total of $14.85 \%$ of counselors have opened the individual WeChat Official Accounts, pushing personal work experience, perception and the feeling of life to show students how to get onto the right path and help the growth of students. 
C. The Results Achieved by the Official Wechat Public Platform of Colleges and Universities in Carrying out the Daily Ideological and Political Education for College Students

1) The establishment of WeChat Official Account of colleges and universities and the corporate account has provided effective information carriers for the daily ideological and political education for college students: Except for timely and comprehensively pushing the news, notices and announcements of the school to the mobile phones of teachers and students, the campus WeChat public platform in colleges universities can provide information, query and help seeking through the service menu of WeChat account. ${ }^{[1]}$ Instance the City College of Dongguan University of Technology, except for establishing the campus WeChat Official Accounts for teachers and students to know about the important news on campus, it also provides campus counseling, interactive community and common query (including the contact information and office location of departments, the public transport information, book retrieval, educational administration system and full view of the campus), providing convenience for students through the "down to earth" service; in addition, the enterprise WeChat OA office system (OS) has been established. Teachers and students of the school can bind with real name and receive the news and notices and meeting notice of departments on campus, handle the renewal of books, query and recharge of food card, participate in voting and questionnaire survey through OA system. Providing the services with practical values through WeChat strengthens the sense of identity of students for the school and improves the work efficiency of teachers and counselors.

2) The campus WeChat public platform contributes to improving the popularity of the campus, expanding the influence of the campus and shaping the school brand: During the period of enrollment propaganda and the month of freshman registration, many colleges and universities push the image advertising video, the pictures of campus scenery and articles to propagandize the characteristics of the campus, in order to attract the attention of candidates for College Entrance Examination at the same time let more people in the society know about the school. For example, on Jun. 19, 2017, Henan University pushed enrollment propaganda video, the Days for Images of Henan University - the Charm of Books through the Official Account of official WeChat. The reading quantity reaches 471,031 . It has been reposted by the WeChat Official Accounts of media such as the People's Daily, China Youth News and Henan Education Press Agency, causing an extensive heated discussion among candidates for College Entrance Examination, students at school, alumnus and the students of other colleges and universities. It has been praised as the most romantic enrollment ad in 2017. In the summer vacation of 2017, the Amazing! Here Comes the Letter of Admission of Wuhan University in 2017 pushed by Wuhan University has a reading quantity of 90,000 and obtains more than 900 likes. ${ }^{[2]}$ Colleges and universities can establish a good image externally and expand the popularity and reputation in society through the effective communication of campus WeChat platform.

\section{Problems of Colleges and Universities in Carrying out the} Daily Ideological and Political Education through Wechat

1) The Official Accounts of official WeChat of colleges and universities are sameness severely and the contents and thoughts are insufficient: The information pushed by WeChat Official Accounts is mainly image-text, voices and videos. Instance the image-text, the authoring software will provide a series of templates. Many editors who push articles will directly edit images and texts through applying the templates. It always causes the similarity of interface style pushed by colleges and universities. Besides, the contents pushed by schools mainly center on trends and activities on campus, information service and voting for activities. It always lacks the characteristics of schools and innovation, leading to the extensive existence of the severe unification. Besides, the contents of many Official Accounts of official WeChat are neither "popular" nor "deep". Most of the contents pushed are excessively formalistic without thoughts and have a poor educational function. It fails to deeply excavate the propaganda and report of some typical deeds, nor setting a good example. Instead, it obtains the click rate only through voting in activities.

2) The interaction between the public platform of official WeChat of colleges and students is inadequate, and the management of public platforms of unofficial WeChat is chaotic: According to the investigation on the public platforms of official WeChat of many colleges and universities, many public platforms only attach importance to pushing the contents at an earlier stage but neglect the interaction between net friends at the later period. The click rate of some articles is low, with few comments or no comment and reply; the click rate of some articles is high, with many comments, but the administrator fails to timely display the comments chosen elaborately; the net friends cannot get timely response from the background of the public platform after consulting on the platform. The situations above will severely influence the ordered operation of the platforms and the leading of thoughts on the network.

3) The counselors seldom interact with students on the WeChat, and the effect of the ideological and political education through WeChat is remarkable: As shown in the survey, only a total of $15.12 \%$ of students communicate with the counselors through WeChat. 30.26\% of students "have added the WeChat number of counselors but never communicate with the counselors". Obviously, students and counselors lack interaction, with a strong sense of distance. With respect to the WeChat Official Account, $14.85 \%$ of counselors have opened the personal WeChat Official Account. The contents pushed by most of them are boring and unreadable. Besides, there are few original articles. Most of 
them are works reposted, with a low click rate. Some Official Accounts become useless accounts because it has not been updated for a long time. What's more, a total of $25.74 \%$ of counselors plan to register personal Official Accounts, and $52.48 \%$ show: they plan to learn even though they have never learnt the technology to operate the Official Accounts.

\section{WAYS TO IMPROVE THE EFFECTIVENESS OF COUNSELORS IN CARRYING OUT THE IDEOLOGICAL AND POLITICAL EDUCATION IN COLLEGES THROUGH WECHAT}

Working on the front line of the daily ideological and political education for college students, the college counselors contact with, communicate with and interact with the college students most frequently, and they are most familiar with the ideological situation of college students. They are advantaged to build the new pattern of the daily ideological and political education for college students through WeChat. Therefore, counselors shall strengthen the learning of network technique and better grasp the application of new media through WeChat and Weibo, strengthen the "user loyalty" of the daily ideological and political education through new media, improving the depth and popularity of contents and attaching importance to the guidance for the ideology and combining WeChat with education, in order to improve the effectiveness of the daily ideological and political education work in colleges and universities.

\section{A. Strengthen the Training for Counselors' Ability in Using Wechat and Improve the Popularity of the Daily Ideological and Political Education}

1) Actively conduct the training related to WeChat knowledge and the skills to use it: The professionals of new media and the journalism and communication shall be invited to serve as the trainers of the counselors, training the functions of WeChat, application skills, the basic technique of the development and management of the WeChat Official Platform of colleges and universities, the shooting and manufacture of micro videos and the basic processing of pictures, letting the counselors base on the reality and practice personally, in order to improve the ability of using the WeChat and serve the daily ideological and political education work.

2) Strengthen the interaction with students on "WeChat": According to the physical truth of students, counselors shall pay close attention to the needs of students, timely find out and help students to solve the practical problems, expressing the contents of the ideological and political education through the vivid language close to the habits of students in the daily communication. Besides, they can actively attach importance to the popular feelings of students on the network, helping students to explain the inactive public feelings, annoyance and confusion through ways and words that are acceptable for students, such as the micro voice, micro video and micro live streaming, using the warm voice, rich expressions and interesting pictures to form the communication, instead of the boring and cold interaction through texts in the past. The timely communication whenever and wherever possible can be used to replace the communication in the past with a fixed time and place, shortening the distance between teachers and students and strengthening the popularity of ideological and political education in daily life.

\section{B. Strengthen the Construction of the Public Platforms of Official Wechat of Colleges and Universities and Create the High Quality Platform for the Ideological and Political Education}

1) Clarify the positioning of the WeChat Official Accounts and improve the effects of education: The WeChat official platforms of colleges and universities are the media to transmit the information on campus. We shall make it into a brand new media that pass the information on campus, becoming "mainstream and grass-root, ideological and recreational, serve the school and serve the students, base on the campus and widely scan the society", in order to lead the thoughts of college students and serve the growth of them. ${ }^{[3]}$ In the mobile internet era, colleges and universities can create the campus WeChat service account or WeChat enterprise account to provide teachers and students with convenient service on campus, such as paying the fees, the renewal of books, the recharging of one-card, meeting notice, questionnaire survey and the query of address book, accelerating the construction of high quality mobile campus application with a high speed and low cost, realizing the mobile teaching, scientific research, management and service. In the second place, when carefully pushing articles in daily life such as the dynamic state of the campus and the information service, the WeChat Official Accounts of colleges must be adept in excavating the typical figures and things around students and pay attention to the establishment of examples and create a good atmosphere of learning and striving for the advanced individuals, stimulating teachers and students to participate in the construction of campus culture. In addition, universities can conduct a series online and offline activities that integrate virtuality and reality on campus culture through the WeChat Official Accounts, in order to attract more college students to participate in the construction of the campus culture, playing the role of master on campus. Meanwhile, it stimulates the sense of identity of students for the school and enhances the cohesion, fully giving play to the educational function of the WeChat official platform of colleges and universities.

2) Attach importance to the construction of the Official Accounts of the official WeChat of student work and the personal WeChat of counselors to improve the quality of service: First, the department of student work in colleges and universities shall establish the Official Accounts of student work to provide the convenient service for the learning and life of students and meet the needs of students, realizing the all-round communication with students, carrying out the ideological and political education on the network through rich forms such as pictures, voices, videos and texts on the 
official platforms. The correct methods are used to guide the thoughts of students and help students to establish the correct world outlook, outlook on life and values. Second, accelerate the construction of the personal Official Accounts of counselors. Counselors can push the original articles, elaborately choose the hot issues among students and analyze and comment on them through the unique perspectives and diversified ways. In this process, they can guide students to interact actively (comment, click the Like and repost), timely reply the comment and message left by students and show them how to get onto the right path, so that they can establish the brand of personal WeChat Official Accounts, attract more students and do better in the student work as well as comprehensively improve the quality of education.

\section{Strengthen the Education on Media Literacy for College Students and Promote College Students to Establish the Correct Concept of the New Media}

As the main force of the audiences of the new media, college students are enjoying the unprecedented convenience that is provided by the new media. However, most of the college students cannot deeply use the new media, but carry out leisure and entertainment through new media. They read all the information obtained and fail to recognize the vulgar information because they are lacking in the rational thinking, analysis and criticism, and they do not know to take new media as the effective tool for self-growth and serving the society. Therefore, it is very necessary to conduct the education of media literacy on students.

First, the curriculum of the media literacy education can be provided. The media literacy of college students can be trained through bringing the curriculum of the media literacy education in college education and combining the practical course with the course of theoretical education. College students will establish a correct idea in using the new media through the implementation of the debate competition, lectures of media literacy and competitions of knowledge about media. Second, the propaganda of the media literacy and the National Internet Civilization Convention for Teenagers can be strengthened. Colleges and universities can establish the position of public opinions in propagandizing the network civilization through "Weibo, WeChat and client side", campus broadcast, TV station, school newspaper, streamer and posters, propagandizing the media literacy on campus and creating a good atmosphere of media and network civilization education. Third, the cognition of college students on the new media of WeChat and the ability to use new media can be strengthened. College students can rapidly grasp the skills to use the new media, recognize the virtual media environment and rationally distinguishing the false information of new media like WeChat and do not break the law and morality through the links that share the skills and knowledge to use new media such as WeChat on the class group or the Moments, popularizing the knowledge about new media through conducting the questionnaire survey of the knowledge about new media and the quiz game of the knowledge about the new media. Fourth, the "opinion leader" of new media can be trained. Student cadres of the party and organizations can be trained about the new media literacy, in order to build a team with influential internet commentators and messengers. The internet opinion leaders that can conduct the ideological and political education can be trained to realize the extensive coverage of leading the thoughts on the internet. They can report and guide timely when inactive public sentiment occurs to help college students to grow in the healthy network community environment.

\section{CONCLUSION}

In conclusion, the popularizing rate of WeChat among the counselors and college students is high, and both of them identify the educational value of WeChat. Some colleges and universities have achieved results in the daily ideological and political education through WeChat. For example, the establishment of the WeChat Official Accounts and corporate account of colleges provides the effective information carrier for the ideological and political education. The establishment of the WeChat public platform on campus has improved the popularity of campus, expanding the influence of campus and shaping the school brand. However, we are still at the exploratory stage and have many problems in taking WeChat as the carrier to conduct the ideological and political education for college students. For example, the Official Accounts of the official WeChat of colleges and universities are severely unified and the contents are not insightful; the interaction between the public platform of the official WeChat of colleges and students is insufficient, and the management of the public platform of unofficial WeChat is chaotic, and the interaction between the counselors and students is inadequate, the effect of ideological and political education through WeChat is indistinctive. Working in the front line of the ideological and political education work of college students, the counselors shall actively discuss the paths to improve the effectiveness of the ideological and political education work through WeChat, strengthen the training of ability to use WeChat and the construction of the public platform of the official WeChat of colleges as well as the education of college students on the media literacy, in order to promote college students to establish the correct concept of new media.

\section{REFERENCES}

[1] Chai Sufang, Liu Pei. The Enhancement of Popularity and Effectiveness of the Ideological and Political Education through WeChat as the Carrier [J], Journal of Hebei University (Philosophy and Social Science), 2017(2):37-45.

[2] Tencent Weixiao. The Ranking List of Official Accounts of Colleges (July) [EB/OL].http://weixiao.qq.com/rank/index.

[3] Sheng Weifang. Research on the Operation Strategy of WeChat Official Platform on Campus [J], Jiannan Literature (Classics), 2013: 318-319. 